\title{
GREEN PUBLIC PROCUREMENT IN THE ACADEMIC LITERATURE
}

\author{
Ionela Corina Chersan ${ }^{1}$, Valentin Florentin Dumitru2 ${ }^{2 *}$, Cătălina Gorgan ${ }^{3}$ \\ and Vasile Gorgan ${ }^{4}$ \\ 1) Alexandru-Ioan Cuza University, Iași, Romania \\ ${ }^{2) 344)}$ Bucharest University of Economic Studies, Romania
}

\section{Please cite this article as:}

Chersan, I.C., Dumitru, V.F., Gorgan, C. and Gorgan, V., 2020. Green Public Procurement in the Academic

Literature. Amfiteatru Economic, 22(53), pp. 82-101.

\section{Article History}

Received: 10 September 2019

Revised: 15 November 2019

Accepted: 17 December 2019

DOI 10.24818/EA/2019/53/82

\begin{abstract}
The study aim is to present a review of the literature dedicated to green public procurement. We analyse traditionally and using a structured literature review 115 articles indexed in Scopus on this topic. The contribution of the paper consists in the development of the knowledge regarding the green procurement in the public domain, by highlighting the main investigations in the literature and their results, identifying the limits, but also the orientation towards future research. The results indicate increased attention paid by researchers to raising awareness of the importance of green procurement and its effect on sustainable development, as well as the need to create tools for implementation by both governments and entities involved in such purchases. We believe that our paper can have an impact on practice and public purchases standards, as it crystallizes the ideas of issuing applicable and useful regulations in terms of green procurement.
\end{abstract}

Keywords: green public procurement, structured literature review (SLR), sustainability, environment

JEL Classification: O13, Q56

\footnotetext{
${ }^{*}$ Corresponding author, Valentin Florentin Dumitru - valentin.dumitru@cig.ase.ro
} 


\section{Introduction}

The economic studies stress the motives (e.g., Nikolaeva and Bicho, 2011), the business models (Schaltegger et al., 2012), and the development of numerous sustainability management tools (Windolph, Schaltegger, and Herzig, 2014), to justify the need to approach sustainability issues. There are pressures exerted by investors, policymakers, and other stakeholders (Yakovleva, Sarkis, and Sloan, 2012), which drive the entities to take measures in this direction.

The literature argues that the initiatives in regard to sustainability and, more specifically, the environment do not change the entities fundamentally internally, but are mostly impression management techniques (Săndulescu and Albu, 2018). We consider it important to address the actual initiatives of the entities in regard to mitigation of the environmental crisis. As such, we discuss the topic of green procurement. Green procurement is vital as it does not involve a single actor from the economy, but an entire supply chain. Besides, it is relevant for both public and private entities. The academic literature considers the green procurement a vital sustainable development tool (Zhu et al., 2013). There are other tools used by the companies (such as integrated reporting, environmental management accounting), but the characteristics of green procurement make it one of the most useful.

The environmental problems with which we are confronted nowadays do not have a precedent and are so severe that they ask for action from all the parties involved. Even though the change in this regard started as a voluntary initiative meant to legitimize the companies (Tilling and Tilt, 2010), nowadays, the contribution of the regulatory authorities is needed. The role of the public sector in the green public procurement (GPP) is twofold: on the one hand, it establishes the procurement policies and, on the other hand, it is a customer. In recent years, many governments (from the European Union, USA and South Africa) have adopted specific environmental policy instruments aimed at stimulating or even imposing green behaviour on both entities and consumers (Nikolaou and Loizou, 2015; Bolton, 2008; Kaufman, 2014; Rainville, 2017; Simcoe and Toffel, 2014; McMurray et al., 2014).

Also, the state is a significant consumer. According to the European Commission's Green Procurement Guide (2007), public authorities can make a significant contribution to sustainable development through their purchasing power of environmentally friendly goods and services. For example, public authorities may purchase low-carbon means of transport for public transport, the construction or purchase of energy efficient buildings, the purchase of environmentally friendly food for canteens and schools, recyclable paper, etc. For instance, in Europe, the public authorities spend around 14\% of the EU's GDP (European Commission, 2019b). The authorities can influence the market, giving an example, but at the same time, they can stimulate the industries in terms of green technologies. The state drives the research and development by directing research funds to the areas considered strategic, such as the environment. According to Walker and Brammer (2012), the government, being concerned about the welfare of the whole society, can stimulate the sustainable management of the supply chain in markets, by requesting a social and environmental responsibility to the suppliers of goods and services, of which could benefit other customers in the market.

By addressing the public sector, the article has the potential to have an impact on practice and public policy regarding GPP. We analyse the results of the implementation of politics and show a path to follow in GPP. From this point of view, it is a study of good practices.

Vol. $22 \cdot$ No. $53 \cdot$ February 2020 
At the same time, the public sector is less studied than the private one (Walker and Brammer, 2012). For these reasons, the objective of our paper is to present a review of the literature in the area of GPP to offer ideas and models of practices to the managers in the public and private sector.

There are many calls for literature reviews in academic journals (for instance, Light and Pilemer, 1984, p. 169). A literature review is a contribution in the field as it provides a foundation on which new studies can be built. In our paper, we use the traditional approach and the structured one conceptualized by Massaro et al. (2016). Our research answers the following three questions: (1) Which is the main topic (policy, GPP in practice, effects of adoptions, catalysts for adoption of GPP, inhibitors of GPP, etc.) on which GPP research is conducted?; (2) Which are the policies which work in the GPP? Which is the impact of the procedures related to the GPP? and (3) Is the research field changing?

The paper is organized as follows. The first section is dedicated to the literature review. The description of the research method follows. After the presentation of the results of the study, our paper ends with the conclusions.

\section{Literature review}

According to the European Union, GPP is "a process whereby public authorities seek to procure goods, services and works with a reduced environmental impact throughout their life cycle when compared to goods, services and works with the same primary function that would otherwise be procured." (European Commission, 2019b). GPP is set within the broader context of sustainable public procurement, which considers the three dimensions of sustainable development: economic, social, and environmental (Walker and Brammer, 2012).

Entities are confronted with various objectives and need to make appropriate decisions, facing dichotomies like shareholder versus stakeholder, financial versus non-financial, single versus multiple measures. In research and practice, GPP is seen many times as a part of the sustainability strategy (Preuss, 2009). Even though when purchasing a product, for instance, first you notice the economic aspect (e.g., the price) and the environmental elements (e.g., determined by the characteristics of the product), it cannot come without a social impact (e.g., in the form of the work of the employees who produced the good). As such, it is challenging to separate the environment from the economic and social pillars.

Kunzlik (2013) believes that EU strategies ("Europe 2020 Strategy" and "EU Sustainable Development Strategy") are trying to orient the huge demand of the public sector towards sustainable and "eco-innovative" procurement in order to stimulate innovation and reach some high standards regarding the environmental performance of the products. The impetus given to eco-innovation must be supported by the requirements of public buyers regarding meeting high ecological standards, including stricter standards than harmonized public procurement standards. Products that meet the environmental criteria will be available to the entire economy, increasing the efficiency of EU resources, improving the usability of the EU industry, and maintaining the international advantage over environmental technologies.

Authorities such as the European Union, the United Nations, EU member states guide sustainable procurement, addressing the three lines of sustainability (European Commission, 2019c). In Romania, for example, "The guide for green public procurement that includes the minimum requirements regarding the environmental protection for certain 
groups of products and services that are required in the specifications" was approved in October 2018 (Ministry of the Environment, 2018). The guide contains minimum environmental protection requirements for green public procurement for priority product groups and/or services: copy and graphic paper, new indoor and outdoor furniture, furniture reconditioning services, collection, and reuse services for the furniture at the end of the lifecycle, food and catering services, transport vehicles, office cleaning products and services, and IT equipment. The main objective of issuing this guide was to provide the contracting authorities with information on the minimum requirements to be provided when elaborating the documentation for the award of GPP contracts in the case of priority products and services, according to the European Commission's Manual on Green Public Procurement.

In the case of GPPs, the government authorities are in a double hypostasis. On the one hand, they impose rules that can lead to the increase of public spending, and on the other, they must finance these expenses, which generates a boomerang effect. An increase in public expenditure appears in the case of granting incentives to entities that make green purchases, too. At the same time, imposing additional taxes for private entities that do not have environmentally friendly behaviour leads to diminishing resources that could be directed towards green procurement.

Price or cost is, in most cases, decisive factor in the purchase decision. In GPP, it is often assumed that products and services are more expensive than non-ecological ones (Min and Gale, 2001). Without denying this, we must show that such an approach is a short-term one. In the long term, GPPs will at least lead to reductions in recycling costs and waste management costs. Thus, the perception that the price of organic products and services is higher is based exclusively on the purchase price, without taking into account the consumption and maintenance costs over the whole life of the respective products. The lifecycle cost of the product (LCC) involves taking into account all the costs incurred during the life of the product, work or service, and may include the costs of externalities (such as greenhouse gas emissions). The use of LCC can lead to a cheaper environmentally friendly product/service, with potential savings on energy, water, fuel, maintenance and replacement and even elimination (European Commission, 2019a). Following a statistical analysis of data from seven European countries, it results that "in fact, costs do not increase, but decrease if goods and services that comply with EU GPP rules are used" (Cazan, 2014, p.1).

The approach in the GPP must be different from that of green procurement in the private sector because in the public sector procurement is made for final consumption (e.g., police/military uniforms, gloves and surgical masks, etc.), as opposed to the private sector where procurement is, at least for the productive sector, within the supply chain. Under these circumstances, most of the time the problem of waste management in the public sector is of the final consumer, that is, it remains in the public sector, whereas in the private sector the producer, who uses goods for the production process, transfers, for the most part, the management waste to the next links in the supply chain (Arvidsson and Stage, 2012).

\section{Research method}

Our research method combines the traditional review with the structured literature review (SLR). The traditional review is "the most common technique in management research" (Denyer and Tranfield, 2006, p. 216) and the value of such works "lies in the fact that they are written by someone with a detailed and well-grounded knowledge of the issue" (Petticrew and 
Roberts, 2008, p. 10). “An SLR is a method for studying a corpus of scholarly literature, to develop insights, critical reflections, future research paths and research questions" (Massaro et al., 2016, p. 2). Our SLR is conducted in ten steps, as suggested by Massaro et al. (2016). In the last two steps, the traditional and SLR methods are combined.

\section{The structured literature review}

Step 1. Literature review protocol

The GPP has the potential to affect not only an entity but a set of organizations located in a country, operating in an industry, applying a framework.

Step 2. Questions that the literature review is setting out to answer

As such, our analysis is set out to answer the following questions:

$R Q 1$ : Which is the main topic (policy, GPP in practice, effects of adoptions, catalysts for adoption of GPP, inhibitors of GPP, etc.) on which GPP research is conducted?

$R Q 2$ : Which are the policies which work in the GPP? Which is the impact of the procedures related to the GPP?

$R Q 3:$ Is the research field changing?

Step 3. Determine the type of studies and carry out a comprehensive literature search

We selected academic articles indexed in the Scopus database. Scopus is an important database for the academic community, and it is used in many countries to assess academic performance. We used as selection criteria the presence of the following terms in the title, abstract, or keywords: "green procurement" or "green purchas*" or "sustainable procurement" or "sustainable purchas*" or "ethical procurement" or "environmental procurement" and "public". We selected the articles and reviews published in journals. One hundred fifty-seven articles resulted. The list of items was prepared on June 24, 2019. Three articles were not published in English, so they were excluded from our database. We read the title and the abstracts for all the pieces. Some of them were excluded from the database because we considered that they are not related with our topic. We downloaded the PDF versions of 115 articles.

The articles included in our sample were published in 72 journals. The journals in which the most significant number of articles on the topic were published are presented in table no. 1.

Table no. 1: The journals which published the most significant number of articles on the topic

\begin{tabular}{|l|r|}
\hline \multicolumn{1}{|c|}{ Top 10 journals } & Number of articles \\
\hline Journal of Cleaner Production & 21 \\
\hline Sustainability & 4 \\
\hline Ecological Economics & 4 \\
\hline Supply Chain Management & 4 \\
\hline Public Money and Management & 3 \\
\hline Natural Resources Forum & 3 \\
\hline Journal of Public Procurement & 3 \\
\hline
\end{tabular}


We notice that out of the seven journals included in our list, four of them are related to the environmental studies. Two of them are dedicated to public sector studies. Finally, one of them is related to supply chain management, which is a significant factor in the procurement.

It is well-known that the number of articles in the economic sciences increased during the last years. The situation with the articles included in our sample is presented in figure no. 1.

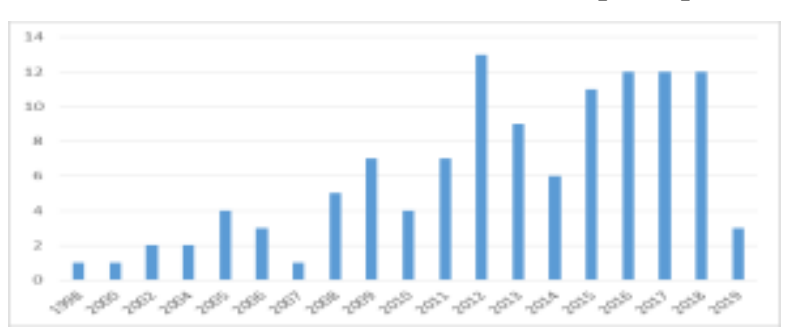

Figure no. 1: The frequency of the articles included in the sample on years

Our time range is of 22 years. The first article on GPP was published in 1998. Even though there is a tendency to increase the number of articles, we notice some interesting facts. For instance, the most significant amount of articles (13) appeared in 2012. Yet, in 2014, only six articles were published. The same amount of papers (12) was published during the last full years. 2019 is not completed yet, so we expect that the end of the year will index other articles on the topic.

\section{Step 4. Measure article impact}

We measured the article's impact using the number of Google Scholar citations. We adopted this approach because all the articles are found on Google Scholar. We present the results in table no. 2.

Table no. 2: The number of citations according to Google Scholar

\begin{tabular}{|l|r|}
\hline \multicolumn{1}{|c|}{ Top 10 articles } & Total number of citations \\
\hline McCrudden, 2004 & 510 \\
\hline Walker and Brammen, 2009 & 437 \\
\hline Green et al., 1998 & 394 \\
\hline Brammer and Walker, 2011 & 389 \\
\hline Preuss, 2009 & 280 \\
\hline Chen, 2005 & 245 \\
\hline Varnäs et al., 2009 & 167 \\
\hline Walker and Brammer, 2012 & 159 \\
\hline Green et al., 2000 & 152 \\
\hline Michelsen and de Boer, 2009 & 144 \\
\hline The average number of citations & 287.7 \\
\hline
\end{tabular}

We notice that there is a high interest from the authors of the GPP procurement to cite the articles included in our sample. The most cited article accumulated over 500 citations. Also, the average number of citations for the ten most cited articles is 287.7. As the pieces included in our sample were published during 20 years, we consider that it is relevant to analyze the citations of the top ten articles per year. These are presented in table no. 3 . 
Table no. 3: Citations per year

\begin{tabular}{|l|r|}
\hline \multicolumn{1}{|c|}{ Top 10 articles } & Citations per year \\
\hline Brammer and Walker, 2011 & 49 \\
\hline Walker and Brammen, 2009 & 44 \\
\hline Testa et al., 2016 & 34 \\
\hline McCrudden, 2004 & 34 \\
\hline Preuss, 2009 & 28 \\
\hline Walker and Brammer, 2012 & 23 \\
\hline Green et al., 1998 & 19 \\
\hline Chen, 2005 & 18 \\
\hline Testa et al., 2012 & 17 \\
\hline Smith et al., 2016 & 17 \\
\hline The average number of citations & 28.19 \\
\hline
\end{tabular}

Seven articles appear in both tables (the most cited articles are also the most quoted per year), which means that the citation of the materials is not necessarily a matter of time. The most cited article has 49 citations per year and 389 in total. Two articles published in 2016 appear in the top of the most cited articles per year, which shows that they are high-quality papers.

Step 5. Define an analytical framework

We derived the analytical framework used for this SLR from Dumay et al. (2016), which started from Guthrie et al. (2012). It consists of the items presented in table no. 4.

Table no. 4: Results of analysis of articles

\begin{tabular}{|l|r|l|r|}
\hline \multicolumn{1}{|c|}{ Item } & Count & \multicolumn{1}{|c|}{ Item } & Count \\
\hline Authors & $\mathbf{1 1 5}$ & Theory used & $\mathbf{1 1 7}$ \\
\hline Academics & 101 & Normative & 3 \\
\hline Practitioners and/or consultants & 3 & Stakeholders & 1 \\
\hline $\begin{array}{l}\text { Academics, practitioners } \\
\text { and/or consultants }\end{array}$ & 11 & Institutional & 3 \\
\hline Authors' provenance & $\mathbf{1 2 8}$ & Other theory & 17 \\
\hline North America & 10 & No explicit theory & 93 \\
\hline Australia and New Zealand & 9 & Research method & $\mathbf{1 7 6}$ \\
\hline Asia & 17 & Theoretical reasoning/ & \\
\hline Europe & 83 & Discursive & 25 \\
\hline Africa & 3 & normative/ policy/ conceptual & 1 \\
\hline South America & 6 & Qualitative & 25 \\
\hline Place of research & $\mathbf{1 1 5}$ & Case study/ field study & 16 \\
\hline North America & 8 & Content analysis/ historical analysis & 31 \\
\hline Australia and New Zealand & 1 & Interview & 26 \\
\hline Asia & 17 & Quantitative & 38 \\
\hline Europe & 73 & Statistical/ econometric analysis/ regression & 14 \\
\hline Africa & 4 & Survey/ questionnaire & \\
\hline South America & 3 & Other/not specified & \\
\hline
\end{tabular}




\begin{tabular}{|l|r|l|r|}
\hline \multicolumn{1}{|c|}{ Item } & Count & \multicolumn{1}{|c|}{ Item } & Count \\
\hline Other/none & 9 & Jurisdiction & $\mathbf{1 1 5}$ \\
\hline Role of the public sector & $\mathbf{1 4 6}$ & $\begin{array}{l}\text { Supranational/ International/ Comparative }- \\
\text { General }\end{array}$ & 20 \\
\hline Buyer & 73 & $\begin{array}{l}\text { Supranational/ International/ Comparative - } \\
\text { Industry }\end{array}$ & 6 \\
\hline Policy-maker & 73 & $\begin{array}{l}\text { Supranational/ International/ Comparative - } \\
\text { Organisational }\end{array}$ & 1 \\
\hline Analyzed topic & $\mathbf{2 4 6}$ & National - General & 34 \\
\hline Policy & 54 & National - Industry & 38 \\
\hline Uptake/practice & 70 & National - Regional & 7 \\
\hline Effects of GPP & 48 & One Organisation & 7 \\
\hline Catalysts of GPP & 49 & Not applicable & 2 \\
\hline Inhibitors of GPP & 25 & Data sources & $\mathbf{1 1 5}$ \\
\hline Frameworks and models & $\mathbf{1 1 5}$ & Corporate information database & 4 \\
\hline EU directives & 1 & Authors' primary data & 52 \\
\hline State & 31 & Intergovernmental organization & 1 \\
\hline Local & 2 & Corporate website or internal data & 3 \\
\hline Multiple frameworks & 48 & Mixed data sources & 40 \\
\hline Designed by the authors & 13 & Other & 15 \\
\hline None & 20 & & \\
\hline
\end{tabular}

Source: Authors' compilation, adapted from Guthrie et al., 2012

Within this section, we answer the first research question: Which is the main topic (policy, GPP in practice, effects of adoptions, catalysts for adoption of GPP, inhibitors of GPP, etc.) on which GPP research is conducted?

As expected, most of the authors are academics. Only eleven articles have co-authors who are academics, practitioners and/or consultants. It is less than $10 \%$ of the entire sample and in our opinion, is a limitation of the research in the area because this is a highly practical topic, and the support of practitioners and/or consultants could be useful.

Most of the authors come from Europe, and most of the research is based in Europe as well. It is an expected result as Europe is the most active region in the world in terms of sustainability (Habek and Wolniak, 2013). Also, many European countries are rules-based, and this directs the interests of the authors towards policy-related aspects. Indeed, more than $56 \%$ of the articles analysing the role of the public sector entities in the GPP as policymakers come from Europe. The finding is in line with Brammer and Walker (2011). The worst represented continents are Asia and Africa. An interesting finding is that for only one article, the place of research is in Australia.

We prepared the list of analysed topic after conducting a comprehensive literature review (Cheng et al., 2018; Appolloni et al., 2014). The articles included in the sample are dedicated, on average, to 2.14 topics. Most of them analyse the uptake of the GPP in practice $(60.87 \%)$, followed by the policy $(46.96 \%)$. The inhibitors of GPP is the least analysed topic $(21.74 \%)$.

Many frameworks were developed by independent organizations (such as ISO) or by the regulatory authorities (such as the state, the European Union) during the recent years. As 
such, some of the articles included in our sample are presenting the GPP in relation with the application of a framework. Most of them are using multiple frameworks (for instance, the European Directives, but also the state regulations). Some authors suggest their own frameworks for the analysis or the implementation of the GPP (Nikolaou and Loizou, 2015; Parikka-Alhola, 2008; Kaufman, 2014; Michelsen and de Boer, 2009; Luttenberger and Luttenberger, 2016; Leal Filho et al., 2019, etc.). Only $11.31 \%$ of the articles do not describe any framework.

An impressive result regards the theory used. As such, $80.87 \%$ of the articles are not based on any theory. This is a limitation of the studies in the domain.

From the research method point of view, most of the articles are based on surveys/questionnaires or another quantitative method, followed by the interviews. This finding is correlated with the fact that many authors use their primary data for these articles. We consider that this finding is normal for the topic studied. Some articles analyze the existence of environmental criteria within the tenders (Parikka-Alhola, 2008; Testa et al., 2016b; Nissinen et al., 2009), and others examine the annual reports or the sites of the entities, using the content analysis as a research method (Pacheco-Blanco and BastanteCeca, 2016; Mansi, 2015). Some articles use surveys/questionnaires as well as interviews to obtain more in-depth data (Michelsen and de Boer, 2009).

The number of comparative studies is limited. As such, most of the studies are conducted at a national level. They adopt a general topic, specific to a country, or a particular theme for one industry. Several studies are comparing green procurement issues, either on countries in the public sector (Young et al., 2016; Nissinen et al., 2009; Walker and Brammer, 2012), or in public and private organizational contexts (Leal Filho et al., 2019; Mashele and Chuchu, 2018; McMurray et al., 2014).

The examined articles can be grouped into several categories according to the analyzed domain/industry, as follows: construction industry (Varnäs et al., 2009; Testa et al., 2016b; Pacheco-Blanco and Bastante-Ceca, 2016 ), health (Oruezabala and Rico, 2012), education (Young et al., 2016; Leal Filho et al., 2019), organic food (Smith et al., 2016), public transport (Aldenius and Khan, 2017), cleaning services (Lundberg et al., 2015), municipalities (Testa et al., 2016a), etc. Most of the articles (46.96\%) address the GPP in general, within one or more countries.

The results obtained by us are similar in some respects to those obtained by Appolloni et al. (2014), although their study involved a review of the literature on green procurement in the private sector. Appolloni et al. (2014) find that it is more challenging to study GPPs because of their particularities and their political implications. Thus, both studies indicate the survey/questionnaire as the research method most commonly used in research on green procurement. Also, the catalysts for green procurement are frequent research topics. In the case of GPPs, we found the preference for studying the practical application of the specific methods and rules. This fact could be explained by the desire to identify the so-called "best practices," which would then be used throughout the public sector. As Hall et al. (2016) show, compliance with the norms and/or imitation of "best practices" are fundamental aspects in the GPP field. In the private sector, competition makes information about practices used in the procurement process more challenging to access. If environmental and financial performance are frequently studied in the case of green procurement in the private sector, in the case of GPPs, environmental performance is a priority. The explanation could 
be more about the difficulty of measuring financial performance in the public sector than the lack of concern about it.

Step 6. Establish literature review reliability

Two authors analysed the first five articles included in the list. After this check, the differences were discussed and reconciled by the authors. They were communicated to the other two authors.

\section{Step 7. Test literature review validity}

As we mentioned earlier, we used a set of keywords to select the articles from the Scopus database. We ran three rounds of searches, and we analysed the results obtained. We consider that the materials chosen are representatives of our study. After extracting the list given by the search in Scopus, we downloaded the articles. The authors read at least the abstract in order to be sure that the article is related with the purpose of this study.

In our study, the internal validity is assured by the following tactics:

- Rival theory: we considered different theories, methods, approaches, opinions, and arguments to explain the results;

- Time series analysis: we analyse the evolution of literature in time. The first paper included in the sample was published in 1998 and the last one in 2019;

- Logic models, matrix, and other data display: we display the data in tables and figures.

Step 8. Code data using the developed framework

We split the sample into four parts in alphabetical order. Each author coded a quarter of the sample. The results were introduced in an excel file. We discussed the results obtained and, when necessary, we adapted the predefined list of items included in excel with other categories considered relevant.

\section{Step 9. Insights and critique}

Although sustainable procurement is increasingly in the focus of global policymakers, there is insufficient information on the extent to which sustainable procurement policies and practices are incorporated into the practice of procurement professionals (Walker and Brammer, 2012). Nikolaou and Loizou (2015) consider that specialized literature has debated less GPP as a policy tool. From the point of view of RQ2 (Which are the policies which work in the GPP? Which is the impact of the procedures related with the GPP?), many studies have analysed the governmental procedures regarding the integration of the environmental criteria in the public offers of purchase (Oruezabala and Rico, 2012; Pacheco-Blanco and Bastante-Ceca, 2016; Varnäs et al., 2009; Nissinen et al., 2009; FaithEll, 2005; Fet et al., 2011; Testa et al., 2016a; Lundberg et al., 2016; Michelsen and de Boer, 2009), the level of use of these criteria in different countries (Nissinen et al., 2009; Fuentes-Bargues et al., 2017), the factors that influence the inclusion of the green criteria in the public auctions (Testa et al., 2012), the effects of including environmental criteria in the offers of purchase (Parikka-Alhola, 2008). The contracting authorities must award a contract based on the most economically advantageous offer (by applying the criteria: price, cost, quality-price ratio, quality-cost ratio). Testa et al. (2016b) point out that the 
decision-makers need to be more involved in establishing a clear definition of the green offers and in creating "standard tools for monitoring the GPP," but the price dominance in the award of the procurement contracts is still observed in the studies (Luttenberger and Luttenberger, 2016; Young et al., 2016). Luttenberger and Luttenberger (2016) recommend the use of environmental life cycle cost analysis, including externalities, although their calculation raises problems. Thus, in addition to pollution and greenhouse gas production, special attention must be paid to the consumption of materials, the consumption of water and energy, etc.

Numerous difficulties related to the GPP were highlighted in the analysed studies. Among them, we mention the lack of clarity of the environmental criteria (Michelsen and de Boer, 2009; Testa et al., 2012; Nissinen et al., 2009), the existence of too generic criteria, which prevents the easy verification by the contracting authority for their compliance (FuentesBargues et al., 2017), the poor presence of environmental criteria in the evaluation of tenders, rarely affecting the awarding decisions (Varnäs et al., 2009; Fuentes-Bargues et al., 2018 ), including them mainly as technical specifications (Testa et al., 2016b). The use of environmental criteria is encountered in the case of national administrations to a greater extent, because they have more resources and better training of personnel on environmental issues (Fuentes-Bargues et al., 2017).

The environmental criteria analysed in the studies are waste disposal during production, use of harmful substances, working environment and environmental management system (Varnäs et al., 2009), energy efficiency of equipment, installations and buildings (FuentesBargues et al., 2018), the use of less chemicals in furniture products and the use of chemicals that are less harmful on health and the environment (Parikka-Alhola, 2008).

Among the benefits of GPPs, the authors include: reducing energy and water consumption, reducing waste and pollution, achieving environmental objectives, high environmental performance standards for goods and services, for example for the private sector, raising awareness of environmental issues, savings, support for innovation, improving the quality of life (Kunzlik, 2013; Leal Filho et al., 2019; Lundberg et al., 2016; Rainville, 2017). Barriers to the implementation of GPPs are lack of political support, legal expertise, practical tools and information, training, cooperation between authorities, limited environmental criteria for goods and services, higher costs, implementation in management systems, etc. (Arvidsson and Stage, 2012; Bala et al., 2008; Boström et al., 2015; Diófási and Valkó, 2014; Leal Filho et al., 2019; McMurray et al., 2014; Varnäs et al. . 2009).

In addition to the constraints caused by high costs, GPPs are dependent on the existence of product suppliers that meet the requirements imposed by government programs or local/internal rules, which may be added and some generated by the specific characteristics of the products requested by customers. Green et al. (2000) believe that more empirical studies are needed to allow a better understanding of how public or private entities act in the context of changes in pressures on environmental issues to which they are subjected by suppliers and/or customers.

Also, it would be useful to analyse the relationship between the costs of the GPP and those subsequent to the use/consumption of the respective goods in order to observe the efficiency of this type of long term purchases.

Although their study did not focus exclusively on the public sector, Boström et al. (2015) identified several proactive and constructive methods that allow the transition to green 
procurement: the search for alternative products; education; how to communicate with suppliers in order to raise their awareness on the issues of interest, as well as developing a good long-term relationship with them; development of internal policies. These methods are also applicable in the public sector, with the observation that the development of a good long-term relationship with a supplier is exposed to the risk of favouring it, especially in the absence of clear procedures regarding the conclusion of contracts.

In order for GPPs to serve as an environmental policy tool, Lundberg et al. (2016) consider that it is essential to evaluate the decisions of the potential suppliers to participate in the public procurement, the total number of bidders and the selection of the bidders on the necessary green criteria. The authors assert that their study indicated a small effect on the behaviour of providers, questioning the political expectations of using GPPs.

Excessive regulation of a domain can also have adverse effects, such as finding solutions to circumvent the law. However, we believe that the awareness of the importance of adopting responsible behaviour towards society in general and the environment, in particular, can be achieved by using GPP as an environmental policy tool, as is the case in South Africa (Bolton, 2008).

For the African countries, Bwanali and Rwelamila (2017) propose as an alternative for infrastructure projects public-private partnerships. Although the authors argue for them (for example, boosting economic growth), we believe that such partnerships present enough risks and disadvantages, such as cumbersome procedures that can prevent the conclusion of contracts (for example, complaints filed at different stages of contracting), corruption, attempt to transfer responsibility between the parties in the event of problems during the performance of the contract.

The effort to raise awareness of the importance of maintaining a clean environment, without financial intervention from the authorities, can be considered a solution for stimulating GPP. Private entities and public authorities should be aware that sustainable development is a general objective of society, but that it cannot be achieved without financial sacrifices (higher costs for green procurement, environmental remediation costs, proper management of waste, etc.).

An insufficient topic debated in the analysed studies is that of reducing consumption as part of a program for improving the global environment. Green et al. (2000) concluded that in an attempt to reduce the level of use, two aspects must be considered: the use of organizations and their innovative activities, in particular, their ability to develop new products and processes, less resource-consuming. Moreover, they suggest that green procurement practices, both in the public and private sectors, must be following the entity's structure and strategy. Under these circumstances, we consider that the development of generally valid GPP practices is difficult, if not impossible, Still, there is a need for a general framework and several "best practices" specific to each industry of the public sector.

Many studies were conducted using surveys. In the outline of the questionnaires, the authors rely on previous studies related to the chosen topic, the use of pilot studies on a small sample (Leal Filho et al., 2019) or previous interviews (Michelsen and de Boer, 2009). Questionnaire respondents are usually experts in the field of sustainable public procurement, practitioners, or researchers (for example managers, key members of the procurement department, government representatives, rectors, representatives of the environmental management system, etc.). Response rates are generally low because many

Vol. $22 \cdot$ No. $53 \cdot$ February 2020 
of the questionnaires are distributed online, participants voluntarily choose to answer or not, and there are incomplete answers that cannot be used in the analysis (for example $10 \%$ - Leal Filho et al., 2019, 18\% - Walker and Brammer, 2012). The sample size was variable, starting with questionnaires from six responses (Fernández-Viñé, 2013) to 2,096 responses (Huang, 2006). Roman (2017) considers that, although a self-administered survey is an advantageous way of collecting data, being cheap and fast, the quality of the data obtained is yet questioned. Leal Filho et al. (2019) propose to complete such research with interviews and/or case studies for a deeper understanding of the issues related to GPP.

In general, the limits of the analysed researches refer to the sample size, the impossibility of the generalizability of data (Arvidsson and Stage, 2012; Bala et al., 2008; Diófási and Valkó, 2014; Faith-Ell, 2005; Mansi, 2015; Mashele and Chuchu, 2018; Leal Filho et al., 2019; Hall et al., 2016; Oruezabala and Rico, 2012; Pacheco-Blanco and Bastante-Ceca, 2016; Walker and Brammer, 2012; Young et al., 2016), how data is collected (Mansi, 2015; McMurray et al., 2014; Oruezabala and Rico, 2012; Pacheco-Blanco and Bastante-Ceca, 2016; Testa et al., 2012; Testa et al., 2016b; Young et al., 2016), lack of a customized approach depending on specific conditions (Aldenius and Khan, 2017; Arvidsson and Stage, 2012; Leal Filho et al., 2019; Oruezabala and Rico, 2012).

\section{Step 10. Develop future research paths and questions}

Within this section, we will answer RQ3: Is the research field changing?

Most of the research is dedicated to developed countries. Even though there are results which show that the differences between GPP in Western and Eastern Europe are not significant (Brammer and Walker, 2011), further studies are needed tailored on this specific setting and conducted by researchers from this part of world, who have access to a bigger range of documents. For instance, Zhu et al. (2013) state that voluntary regulations may hurt GPP practices. While this statement may be right for China, it may not be valid in another context, which is characterized by other cultural/law factors. Thus, studies based in different countries may be needed for a generalization of the aspects.

At the same time, the authors urge further research related to the barriers in the GPP domain, such as training and support, bureaucracy, culture (Aragão and Jabbour, 2017), cultural, social, and institutional barriers (Zhu et al., 2013).

There is a need for conceptual clarification for green and sustainable public sector food procurement (Smith et al., 2016), which is seen in the percentage of theoretical articles included in our sample $(21.74 \%)$. Smith et al. (2016) also notice the fact "that there is a scarcity of data and indicators" in the domain. The opinion is also supported by our finding that most of the authors use their primary data, mostly obtained through interviews or surveys. As such, there is a need for more empirical studies dedicated to the topic.

In line with the results reported by our study, Grandia et al. (2015) and Chiarini et al. (2017) make a call for comparative studies, Roman (2017) considers that an investigation "incorporating institutional, stakeholder and transformational leadership theories" would be interesting.

Fet et al. (2011) consider that a holistic approach is needed, linking "ecological thinking" to the general procurement strategies of local public authorities/municipalities. 
In the context of many studies addressing the issue of value chain management, Mashele and Chuchu (2018) believe that future research could extend the analysis on the influence of compliance with GPP rules by including the impact of collaboration with suppliers and by analysing the influence of GPP on overall performance. Using the stakeholder theory, institutional theory, and PESTEL framework, the authors consider that it would be of interest to check the results if other research frameworks are used as the basis of the same study.

Further research is needed to clarify the inclusion of environmental criteria in the tenders and their actual use in the selection of suppliers (for example, understanding the discrepancy between the degree to which municipalities declare that in the final selection of suppliers they take into account the environmental aspects and the perception of that have potential suppliers, the search for possible relationships between an increased use of environmental criteria in the tenders and a possible increased use in the final selection of the supplier - Michelsen and Boer, 2009; Faith-Ell, 2005; Fet and et al., 2011), identifying the stages of the procurement process in which environmental criteria are included and analysing the role they play in the award of the contract (Testa et al., 2012), checking whether the projects that contained more environmental preferences were more expensive than others (Varnäs et al., 2009), the development of assessment tools for the environmental criteria in the contracting process (Fuentes-Bargues et al., 2018), analysis of the extent to which the contract award decisions were influenced by environmental considerations (Testa et al., 2016b), elaboration of the criteria for environment that quantifies the provisions proposed by the bidders (Fuentes-Bargues et al., 2017).

Testa et al. (2012) argue that, in the future, specialists should establish whether there are differences in the implementation of GPPs between product categories and for which public authorities have encountered greater obstacles, to analyse the effects of different types of environmental criteria, such as performance and functional criteria and to investigate the synergies between the available European environmental policy instruments, including GPPs, the eco-label, EMAS and the environmental footprint of the product, to highlight the strengths and weaknesses and ways to improve these synergies. Future research should clarify the effect of GPPs on economic systems and examine whether GPPs guide entities and supply chains towards greener development, supporting resource-saving and environmental innovation (Grose and Richardson, 2014).

Future research directions could include analysing how GPP information is presented in annual reports. Using a GPP index, Mansi (2015) examines the annual reports of the central public sector in India. The author proposes to perform the analysis in other countries, to develop the index structure, to use additional reports and case studies to understand public procurement better. It could also be aimed at exploring the internal and external factors that affect the procurement process and identifying the barriers that hinder this process in the case of developing countries.

Rainville (2017) believes that future studies should be conducted to answer questions about the role of standards and standardization in promoting sustainable development, but also on the implementation of GPPs, on which the expected benefits depend largely. A review of regular environmental policy instruments could be done to identify the power exercised by GPPs in governing entities and the effects of legislation, including environmental taxes on their decisions (Nikolaou and Loizou, 2015; Viñé et al., 2013). 


\section{Conclusions}

The objective of our research was to present a review of the specialized literature on GPP. Through the applied research methodology, we noticed that most studies are conducted at a national level, most often being targeted either a country-specific topic or an industryspecific topic. In these circumstances, we consider that the development of generally valid GPP practices is difficult, if not impossible. Still, there is a need for a general framework and several "best practices" specific to each component of the public sector. Once these "best practices" have been defined for the GPP, there is a need for promotion and dissemination mechanisms that work.

GPP is no longer regarded as having only an impact on the environment. Now it is considered in an integrated way, taking into account the environmental safety, the effect on the market (through the diversification of the demand for organic products), the capacity for innovation of companies, the need to reduce consumption, etc.

Buyers need to change their public procurement practices to include in the selection criteria the environmental, social, and economic dimensions of GPPs, such as content (made from natural resources), recyclability, biodegradable nature, procurement of local products, price, and quality.

To develop best practices in GPP, attention is needed from practitioners, decision-makers, and researchers. There is a need for broader involvement of practitioners in conducting studies because they may have a more in-depth and more complete view on the elements related to GPP.

GPP is an area of interest that should be developed in the future. The results of research can help public authorities, project managers, suppliers, other stakeholders in establishing and disseminating best practices and in the effective implementation of GPP (Fuentes-Bargues et al., 2017), especially as it is likely that the adoption of GPP practices will expand in the coming years (Testa et al., 2016b). Moreover, it is necessary to examine how sustainable development objectives are achieved through GPP. The research field is evolving to address the social, economic, and environmental aspects regarding public procurement.

It would be useful to study how e-procurement tools and other forms of e-commerce could be developed to support different types of sustainable procurement and to reconcile the trade-offs between them. Besides, the role of various kinds of e-commerce, other than electronic purchases, within the sustainable supply chain needs to be analysed (Walker and Brammer, 2012).

Future research should enable understanding of both the concrete effects of GPP on the environment (for example, carbon footprint) and markets, as well as the real role of GPP as a stimulus for ecological innovation and ecological markets. Policies that affect the level of GPP implementation and which of them have the most significant influence on the environmental performance of public entities could be analysed (Testa et al., 2016b). Further research should examine the current state of GPP implementation, provide incentives for the development of tools that encourage GPP (Fuentes-Bargues et al., 2018; Viñé et al., 2013), analyse how the government should be involved in the development of voluntary standards as a starting point in designing public procurement policies (Simcoe and Toffel, 2014).

For future research it is proposed to extend the sample, to use interviews to obtain more detailed and specific information, but also to collect data and from other sources, for 
example combining content analysis with questionnaires to identify the level of GPP of entities (Testa et al., 2016b), testing the application of the GPP in different contexts (Leal Filho et al., 2019) and choosing the strategy (Aldenius and Khan, 2017).

The results of the study are encouraging, in the sense that, at least on a declarative level, some public entities, such as universities, seem to understand their role in achieving the objects of sustainable development (Leal Filho et al., 2019). However, a significant challenge lies in the fact that the integration of GPP requires important organizational changes inside and outside the entities (Young et al., 2016).

One of the contributions of the paper is that we make an SLR using the model suggested by Massaro et al. (2016) and validated in 115 other research articles, according to Google Scholar. Our study is more comprehensive than a study conducted on an isolated sample because it not only analyses a situation, but more than 100, through the revised articles that are representative of the studied field. They have been published in leading journals and have received numerous citations in other studies. By reviewing the literature, we showed the realities, but we also identified the perspectives in the research field. We also present GPP opportunities, for example, for improving practices in local administrations. Any form of literature review has "has the potential to guide managers by providing ideas, illustrations and recommendations for practice" (Denyer and Tranfield, 2006, p. 216).

The limits of the research refer to the selection of articles. We consider the Scopus database to be the best option, but some very good articles are not included in it. However, using a transparent selection methodology and due to a large number of articles studied, we consider that the sample was representative. Defining the sample differently is a future research direction.

\section{References}

Aldenius, M. and Khan, J., 2017. Strategic use of green public procurement in the bus sector: Challenges and opportunities. Journal of Cleaner Production, 164, pp.250-257.

Appolloni, A., Sun, H., Jia, F. and Li, X., 2014. Green Procurement in the private sector: a state of the art review between 1996 and 2013. Journal of Cleaner Production, 85, pp.122-133.

Aragão, C.G. and Jabbour, C.J.C., 2017. Green training for sustainable procurement? Insights from the Brazilian public sector. Industrial and Commercial Training, 49(1), pp.48-54.

Arvidsson, A. and Stage, J., 2012. Technology-neutral green procurement in practice - an example from Swedish waste management. Waste management \& research: the journal of the International Solid Wastes and Public Cleansing Association, ISWA. 30, pp.519-523.

Bala, A., Muñoz, P., Rieradevall, J. and Ysern, P., 2008. Experiences with greening suppliers. The Universitat Autònoma de Barcelona. Journal of Cleaner Production, 16(15), 2008, pp.1610-1619.

Bolton, P., 2008. Protecting the environment through public procurement: The case of South Africa. Natural Resources Forum, 32, pp.1-10.

Boström, M., Gilek, M., Hedenström, E. and Jönsson, A.M., 2015. How to achieve sustainable procurement for "peripheral" products with significant environmental impacts. Sustainability: Science, Practice and Policy, 11(1), pp.21-31. 
Brammer, S. and Walker, H., 2011. Sustainable procurement in the public sector: an international comparative study. International Journal of Operations \& Production Management, 31(4), pp.452-476.

Bwanali, S. and Rwelamila, P. D., 2017. Public Private Partnerships: A possible alternative for delivery of infrastructure projects in Africa. International Journal of Construction Supply Chain Management, 7(3), pp.93-109.

Cazan, R., 2014. Achiziții publice ecologice în România - Protecția mediului prin cheltuieli publice responsabile, [online], Centrul pentru Politici Durabile Ecopolis. Available at: <https://www.ecopolis.org.ro/media/Achizitii\%20publice\%20ecologice\%20in\%20roma nia-final.pdf> [Accessed 25 July 2019].

Chen, C.-C., 2005. Incorporating green purchasing into the frame of ISO 14000. Journal of Cleaner Production, 13(9), pp.927-933.

Cheng, W., Appolloni, A., D’Amato, A. and Zhu, Q., 2018. Green public procurement, missing concepts and future trends - a critical review. Journal of Cleaner Production, 176, pp.770-784.

Chiarini, A., Opoku, A. and Vagnoni, E., 2017. Public healthcare practices and criteria for a sustainable procurement: A comparative study between UK and Italy. Journal of Cleaner Production, 162, pp.391-399.

Denyer, D. and Tranfield, D., 2006. Using qualitative research synthesis to build an actionable knowledge base. Management Decision, 44(2), pp.213-227.

Diófási, O. and Valkó, L., 2014. Step by Step Towards Mandatory Green Public Procurement. Periodica Polytechnica Social and Management Sciences, 22(1), pp.21-27.

Dumay, J., Bernardi, C., Guthrie, J. and Demartini, P., 2016. Integrated reporting: A structured literature review. Accounting Forum, 40(3), pp.166-185.

European Commission, 2019a. Life-cycle costing. [online] Available at: <https://ec.europa.eu/environment/gpp/lcc.htm> [Accessed 30 July 2019].

European Commission, 2019b. What is GPP. [online] Available at: <https://ec.europa.eu/environment/gpp/what_en.htm> [Accessed 30 July 2019].

European Commission, 2019c. GPP National Action Plans. [online] Available at: <https://ec.europa.eu/environment/gpp/action_plan_en.htm> [Accessed 30 July 2019].

Faith-Ell, C., 2005. The introduction of environmental requirements for trucks and construction vehicles used in road maintenance contracts in Sweden. Corp. Soc. Responsib. Environ. Mgmt., 12, pp.62-72.

Fernández-Viñé, M.B., Gómez-Navarro, T. and Capuz-Rizo, S.F., 2013. Assessment of the public administration tools for the improvement of the eco-efficiency of Small and Medium Sized Enterprises. Journal of Cleaner Production, 47, pp.265-273.

Fet, A., Michelsen, O. and Boer, L., 2011, Green public procurement in practice - The case of Norway. Society and Economy, 33(1), pp.183-198.

Fuentes-Bargues, J.L., Ferrer-Gisbert, P.S. and González-Cruz, M.C., 2018. Analysis of Green public procurement of works by Spanish public universities. International Journal of Environmental Research and Public Health, 15(9), p.1888

Fuentes-Bargues, J.L., González-Cruz, M.C. and González-Gaya, C., 2017. Environmental criteria in the spanish public works procurement process. International Journal of Environmental Research and Public Health, 14(2), p.204 
Grandia, J., Steijn, B. and Kuipers, B., 2015. It is not easy being green: increasing sustainable public procurement behaviour. Innovation, 28(3), pp. 243-260.

Green, K., Morton, B. and New, S., 2000. Greening Organizations: Purchasing, Consumption, and Innovation. Organization and Environment, 13(2), pp. 206-225.

Green, K., Morton, B. and New, S., 1998. Green purchasing and supply policies: Do they improve companies' environmental performance?. Supply Chain Management, 3(2), pp. 89-95.

Grose, J. and Richardson, J., 2014. Strategies to identify future shortages due to interruptions in the health care procurement supply chain and their impact on health services: A method from the english national health service. Journal of Health Services Research and Policy, [e-journal] 19(1), pp.19-26. DOI: 10.1177/1355819613502172

Guthrie, J., Ricceri, F. and Dumay, J., 2012. Reflections and projections: A decade of intellectual capital accounting research. The British Accounting Review, 44(2), pp.68-82.

Habek, P. and Wolniak, R., 2013. European Union regulatory requirements relating to sustainability reporting. The case of Sweden. Scientific Journals, 34(106), pp.40-47.

Hall, P., Löfgren, K. and Peters, G., 2016. Greening the Street-Level Procurer: Challenges in the Strongly Decentralized Swedish System. J Consum Policy, [e-journal] 39, pp.467-483 DOI 10.1007/s10603-015-9282-8.

Huang, P., Zhang, X. and Deng, X., 2006. Survey and analysis of public environmental awareness and performance in Ningbo, China: a case study on household electrical and electronic equipment. Journal of Cleaner Production, 14(18), pp.1635-1643.

Kaufman, N., 2014. Overcoming the barriers to the market performance of green consumer goods. Resource and Energy Economics, 36, pp.487-507.

Kunzlik, P., 2013. Green Public Procurement -European Law, Environmental Standards and "What To Buy" Decisions. Journal of Environmental Law, 25(2), pp.173-202.

Leal Filho, W., Skouloudis, A., Brandli, L.L., Salvia, A.L., Avila, L.V. and RaymanBacchus, L., 2019. Sustainability and procurement practices in higher education institutions: Barriers and drivers. Journal of Cleaner Production, 231, pp.1267-1280.

Lundberg, S., Marklund, P.O., Strömbäck, E. and Sundström, D., 2015. Using public procurement to implement environmental policy: an empirical analysis. Environmental Economics and Policy Studies, 17(4), pp.487-520

Luttenberger, A. and Luttenberger, L.R., 2017. Sustainable procurement and environmental life-cycle costing in maritime transport. WMU Journal of Maritime Affairs, 16(2), pp.219-231.

Mansi, M., 2015 Sustainable procurement disclosure practices in central public sector enterprises: Evidence from India. Journal of Purchasing \& Supply Management, 21, pp.125-137.

Mashele, F. and Chuchu, T., 2018. An empirical investigation into the relationship between sustainability and supply chain compliance within the South African Public and the private sector. Journal of Business and Retail Management Research, 12(2), pp.121-132.

Massaro, M., Dumay, J. and Guthrie, J., 2016. On the shoulders of giants: Undertaking a structured literature review. Accounting, Auditing \& Accountability Journal, 29, pp.767-801. 
McCrudden, C., 2004. Using public procurement to achieve social outcomes. Natural Resources Forum, 28(4), pp.257-267.

McMurray, A., Islam, Md.M., Siwa, C. and Fien, J., 2014. Sustainable procurement in Malaysian organizations: Practices, barriers and opportunities. Journal of Purchasing \& Supply Management, 20, pp.195-207.

Michelsen, O. and de Boer, L., 2009. Green procurement in Norway; a survey of practices at the municipal and county level. Journal of Environmental Management, 91, pp.160-167.

Min, H. and Galle, W.P., 2001, Green purchasing practices of US firms. International Journal of Operations \& Production Management, 21(9), pp.1222-1238.

Ministerul Mediului, 2018. ORDIN Nr. 1068/1652/2018 din 4 octombrie 2018 pentru aprobarea Ghidului de achiziţii publice verzi care cuprinde cerinţele minime privind protecţia mediului pentru anumite grupe de produse şi servicii ce se solicită la nivelul caietelor de sarcini. [online] Available at: <http://anap.gov.ro/web/wp-content/uploads/ 2018/11/ORDIN-Nr-1068-Achizitii-verzi.pdf> [Accessed 15 July 2019].

Nikolaeva, R. and Bicho, M., 2011. The role of institutional and reputational factors in the voluntary adoption of corporate social responsibility reporting standards. Journal of Academic Marketing Science, 39(1), pp.136-157.

Nikolaou, I. and Loizou, C., 2015. The Green Public Procurement in the midst of the economic crisis: is it a suitable policy tool?. Journal of Integrative Environmental Sciences, [e-journal] 12(1), pp.49-66. DOI: 10.1080/1943815X.2014.993657.

Nissinen, A., Parikka-Alhola, K. and Rita, H., 2009. Environmental criteria in the public purchases above the EU threshold values by three Nordic countries: 2003 and 2005. Ecological Economics, 68, pp.1838-1849.

Oruezabala, G. and Rico, J.C., 2012. The impact of sustainable public procurement on supplier management - The case of French public hospitals. Industrial Marketing Management, 41, pp. 573-580.

Pacheco-Blanco, B. and Bastante-Ceca, M.J., 2016, Green public procurement as an initiative for sustainable consumption. An exploratory study of Spanish public universities. Journal of Cleaner Production, 133, pp.648-656

Parikka-Alhola, K., 2008. Promoting environmentally sound furniture by green public procurement. Ecological Economics, 68, pp.472-485.

Petticrew, M. and Roberts, H., 2008. Systematic reviews in the social sciences: A practical guide. Oxford, UK: Wiley-Blackwell.

Preuss, L., 2009. Addressing sustainable development through public procurement: The case of local government. Supply Chain Management, 14(3), pp.213-223.

Rainville, A., 2017. Standards in Green Public Procurement - A framework to enhance innovation. Journal of Cleaner Production, [e-journal] 16, pp.1029-1037. DOI: 10.1016/j.jclepro.2016.10.088.

Roman, A.V., 2017. Institutionalizing sustainability: A structural equation model of sustainable procurement in US public agencies. Journal of Cleaner Production, 143, pp.1048-1059. 
Săndulescu, M.S. and Albu, C.N., 2018. Impression management in the letters to shareholders of listed entities: A Romanian case study. Accounting and Management Information Systems, 17(3), pp.353-373.

Schaltegger, S., Lüdeke-Freund, F. and Hansen, E., 2012. Business cases for sustainability. The role of business model innovation for corporate sustainability. International Journal of Innovation and Sustainable Development, 6(2), pp.95-119.

Simcoe, T. and Toffel, M., 2014. Government green procurement spillovers: Evidence from municipal building policies in California. Journal of Environmental Economics and Management, 68, pp.411-434.

Smith, J., Andersson, G., Gourlay, R., Karner, S., Mikkelsen, B.E., Sonnino, R. and Barling, D., 2016. Balancing competing policy demands: The case of sustainable public sector food procurement. Journal of Cleaner Production, 112, pp.249-256.

Testa, F., Annunziata, E., Iraldo, F. and Frey, M., 2016a. Drawbacks and opportunities of green public procurement: an effective tool for sustainable production. Journal of Cleaner Production, 112(3), pp. 1893-1900

Testa, F., Grappio, P., Gusmerotti, N., Iraldo, F. and Frey, M., 2016b. Examining green public procurement using contentanalysis: existing difficulties for procurers and useful recommendations. Environment, Development and Sustainability, 18(1), pp.197-219.

Testa, F., Iraldo, F., Frey, M., Daddi, T., 2012. What factors influence the uptake of GPP (green public procurement) practices? New evidence from an Italian survey. Ecological Economics, 82, pp.88-96.

Tilling, M.V. and Tilt, C.A., 2010. The edge of legitimacy. Voluntary social and environnemental reporting in Rothmans' 1956-1999 annual reports. Accounting, Auditing and Accountability Journal, 23(1), pp.55-81.

Varnäs, A., Balfors, B. and Faith-Ell, C., 2009. Environmental consideration in procurement of construction contracts: current practice, problems and opportunities in green procurement in the Swedish construction industry. Journal of Cleaner Production, 17(13), pp.1214-1222.

Walker, H. and Brammer, S., 2009. Sustainable procurement in the United Kingdom public sector. Supply Chain Management, 14(2), pp.128-137.

Walker, H. and Brammer, S., 2012. The relationship between sustainable procurement and e-procurement in the public sector. International Journal of Production Economics, 140(1), pp.256-268.

Windolph, S.E., Schaltegger, S. and Herzig, C., 2014. Implementing corporate sustainability. What drives the application of sustainability management tools in Germany? Sustainability Accounting, Management and Policy Journal, 5(4), pp.378-401.

Yakovleva, N., Sarkis, J. and Sloan, T., 2012. Sustainable benchmarking of supply chains: the case of the food industry. International Journal of Production Resources, 50, pp.1297-1317.

Young, S., Nagpal, S. and Adams, C., 2016. Sustainable Procurement in Australian and UK Universities. Public Management Review, 18(7), pp.993-1016.

Zhu, Q., Geng, Y. and Sarkis, J., 2013. Motivating green public procurement in China: An individual level perspective. Journal of Environmental Management, 126, pp.85-95. 